\title{
Создание биоцидных препаратов «Тефлекс» от синтеза нового полимера до линейки продукции. Часть 1. Разработка технологии получения био- цидных препаратов «Тефлекс»
}

\author{
В.Т.Ерофеев, МГУ им. Н. П. Огарева, Саранск \\ Д.А.Светлов, «Софт Протектор», Санкт-Петербург \\ В.Ф.Смирнов, ННГУ им. Н.И.Лобачевского, Н. Новгород \\ Л.А.Краева, НИИЭМ имени Пастера, С.-Петербург \\ М.А.Лубченков, «Софт Протектор», Финляндия \\ Д.Д.Светлов, студент ВШБиПП, Санкт-Петербург
}

В статье приводится обзор отечественной и зарубежной литературы по биоповреждениям в зданиях и сооружениях, методам биозащиты материалов и изделий и результатам исследований по технологии получения биоцидного препарата на основе соединений гуанидина. Показано, что повреждения строительных материалов, вызванные размножением на них бактерий и мицелиальных грибов, представляют серьёзную опасность как для конструкций зданий и сооружений, так и для здоровья людей. Одним из наиболее эффективных способов защиты строительных материалов и конструкций от поражений микроорганизмами является применение биоцидных соединений. К отвечающим современным требованиям нетоксичным биоцидным препаратам относятся полимеры и олигомеры природного или синтетического происхождения. Среди широкого спектра полимерных биоцидов выделяется группа соединений, содержащих в своём составе гуанидиновую группировку (ПГМГ). Приводятся результаты исследования авторов по технологии получения модифицированных препаратов ПГМГ. Выявлено увеличение биоцидного эффекта при их модификации добавками кислот. Установлена комплексообразующая способность макромолекул ПГмГ с хлоридом железа. Приведены результаты исследований по снижению токсичности ПГМГ посредством удаления аммиака при температурной обработке. В итоге получены биоцидные композиции с широким спектром свойств, пригодные для получения биоцидных композиционных строительных материалов путём снижения обсеменённости микроорганизмами помещений, приборов, аппаратов, изделий, конструкций. Приведён перечень производимых по разрабатываемым технологиям биоцидных препаратов «Тефлекс».

Ключевые слова: долговечность конструкций, биоповреждения, микроорганизмы, защита от биоповреждений, биоцидные препараты, полимерные биоциды, производные гуанидина, полигексаметиленгуанидин - хлорид (ПГМГ-Х), ПМГГ-фосфат (ПГМГ-Ф), препараты «Тефлекс».

Creation of Teflex Biocidal Preparations from the Synthesis of a New Polymer to the Product Line.
Part 1. Development of technology for producing biocidal preparations "Teflex"

V.T.Erofeev, Ogarev Mordovia State University, Saransk

D.A.Svetlov, "Soft Protector", St. Petersburg

V.F.Smirnov, UNN named after N.I.Lobachevsky, N. Novgorod L.A.Kraeva, Saint-Petersburg Pasteur Institute, St. Petersburg

M.A.Lubchenkov, "Soft Protector", Finland

D.D.Svetlov, GSB\&FS student, St. Petersburg

The article provides an overview of domestic and foreign literature on biodeterioration in buildings and structures, methods of bioprotection of materials and products, and research results on the technology for producing a biocidal preparation based on guanidine compounds. It is shown that damage to building materials caused by the multiplication of bacteria and mycelial fungi on them represents a serious danger both to the structures of buildings and to human health. One of the most effective ways to protect building materials and structures from damage by microorganisms is the use of biocidal compounds. Non-toxic biocidal preparations that meet modern requirements include polymers and oligomers of natural or synthetic origin. Among a wide range of polymer biocides, a group of compounds containing a guanidine moiety (PHMG) is distinguished. The results of a study of the authors on the technology for producing modified preparations of PHMG are presented. An increase in the biocidal effect was revealed during their modification with acid additives. The complexing ability of PHMG macromolecules with iron chloride has been established. The results of studies to reduce the toxicity of PHMG by removing ammonia during heat treatment are presented. As a result, we obtained biocidal compositions with a wide range of properties suitable for producing biocidal composite building materials reducing the contamination of microorganisms in rooms, devices, apparatuses, products, structures. The list of Teflex biocidal preparations produced by the developed technologies is given.

Keywords: durability of structures, biodeterioration, microorganisms, protection against biodeterioration, biocide preparations, polymer biocides, guanidine derivatives, 
polyhexamethyleneguanidine chloride (PHMG-X), PMHG phosphate (PHMG-F), Teflex preparations.

Повреждения строительных материалов, вызванные размножением на них бактерий и грибов, могут представлять серьёзную опасность как непосредственно для конструкций зданий и сооружений, так и для здоровья людей [1-18].

Эта проблема особенно актуальна для городов, в пределах которых находятся крупные промышленные предприятия мясомолочной, рыбной и консервной промышленности, сельскохозяйственные предприятия, а также производства, на которых путём микробиологического синтеза изготавливаются различные лекарственные препараты.

Поражения наблюдаются как в старых, так и в новых постройках. Эксперименты по изучению поведения материалов в условиях воздействия микроорганизмов и натурные обследования зданий и сооружений свидетельствуют о снижении прочностных показателей, разрушении бетонных и кирпичных изделий, отслаивании штукатурных покрытий, обесцвечивании или образовании пигментных пятен на лакокрасочных покрытиях, растворении стекла, разбухании шпатлёвок [2; 5; 8; 22]. Более всего подвержены биоразрушению целлюлозосодержащие материалы. Например, мицелиальные грибы за несколько месяцев способны уничтожить конструкции из древесных материалов. При благоприятных условиях микроорганизмы разрушают железобетон, металлы и т.д. Исследования показывают, что во многих зданиях и сооружениях заражённость помещений микроорганизмами превышает предельно допустимую норму в несколько десятков и даже сотен раз [5]. При этом процессы биоразрушений прогрессируют с каждым годом.

На ранней стадии поражения здание ещё можно отремонтировать, однако если процесс зашёл слишком далеко, оно подлежит сносу.

Наиболее активно подвергаются воздействию микроорганизмов исторические центры городов. Подавляющее большинство музеев, библиотек, архивов располагаются в зданиях более чем вековой давности. Строительные конструкции этих зданий, даже несмотря на ремонт, имеют нарушенную гидроизоляцию из-за геологических и климатических особенностей региона.

Обследование зданий различного назначения (в том числе и только что отремонтированных) в Санкт-Петербурге, проведённое в рамках инициативного исследования Международной академии наук экологии, безопасности человека и природы (МАНЭБ), показало, что в центре города большинство (80-90\%) зданий вследствие нарушения горизонтальной и вертикальной гидроизоляции, протечек кровель и т.п. поражены различными организмами: бактериями, микроскопическими грибами (микромицетами), домовыми грибами, водорослями, лишайниками [19; 20]. Процессы биоповреждения в производственных помещениях перерабатывающих предприятий резко обостряют проблемы сохранения продовольствия: зерна и муки на мукомольных предприятиях, молока и мяса на мясомолочных комбинатах ит.д. [9].

Система мер по защите элементов объектов строительства от биоповреждений осуществляется по двум направлениям: обеспечение снижения отрицательного воздействия микроорганизмов на биологическое разрушение материалов; получение новых фунгицидных и биостойких строительных материалов, предусматривающих использование биоцидных добавок.

Один из наиболее эффективных и длительно действующих способов защиты строительных материалов и конструкций от поражений микроорганизмами - применение биоцидных соединений [2]. Последние вводят в состав материала при его изготовлении или методом пропитки. Кроме того, на поверхность материалов и изделий, подверженных микробному поражению, наносят биоцидные лакокрасочные и клеящие покрытия [2].

Биоциды, использующиеся для уничтожения микроорганизмов, по механизму оказываемого воздействия можно разделить на две группы: фунгициды - для защиты материалов и изделий от повреждения грибами (главным образом плесневыми); бактерициды - для защиты от гнилостных, слизеобразующих, кислотообразующих и других бактерий. В основе токсического действия биоцидных добавок лежит их способность ингибировать активность ферментов и определённые реакции метаболизма микроорганизмов, угнетать дыхание, нарушать их клеточные структуры [2; 22; 24]. Фунгицид, контактируя с клеточной оболочкой гриба, проникает в клетку и вступает во взаимодействие с её компонентами, подавляя биосинтез. Многие классы фунгицидов вызывают дезорганизацию клеточных мембран, что приводит к увеличению проницаемости последних, выходу белков и эндогенных ферментов из клеток мицелия в культуральную жидкость. Фунгициды подавляют развитие микроорганизмов также за счёт снижения поступления питательных веществ из внешней среды в клетки гриба.

В результате проведённого анализа отечественной и зарубежной научно-технической литературы выявлены отвечающие современным требованиям нетоксичные биоцидные препараты [15-18]. К ним в большей мере относятся полимеры и олигомеры природного или синтетического происхождения [2; 5; 25-27]. Интерес к использованию препаратов этого класса для борьбы с вредной микрофлорой обусловлен возможностью решения проблем экологии и защиты как окружающей среды, так и различных материалов от воздействия окружающей среды, обеспечения длительности воздействия. Как правило, большинство полимерных антимикробных препаратов представляют собой макромолекулу, несущую положительный заряд, обусловленный наличием в структуре атомов азота. Полимеры, содержащие четвертичные аммониевые основания, хорошо растворимы в воде и проявляют биоцидную активность в концентрации, равной 1\%. Эффективность биоцидного действия определяется величиной заряда атома азота, обеспечивающей взаимодействие с бактериальной клеткой, мембраны которой заряжены отрицательно [5]. Последовательность стадий взаимодействия, приводящих к гибели клетки, включает: адсорбцию биоцида на поверхности клетки, диффузию через мембрану, связывание с цитоплазматической мембраной и её разрушение, в результате чего происходит выделение цитоплазмы наружу и гибель клетки. Способность связываться с мембранами клеток определяется наличием положительного за- 
ряда в полимере, а эффективность воздействия биоцида зависит от структуры заместителей у атомов азота и от природы микроорганизма. Например, против микобактерий туберкулёза более эффективным оказался препарат, содержащий ненасыщенные, двойные связи [2; 5]. Существенное влияние на активность биоцидных полимеров оказывает природа заместителей у атомов азота, которая определяет величину заряда и плотность ионогенных групп в макромолекуле. Сопоставление активности различных катионныхполимеров показало, что увеличение плотности заряда введением в мономер нескольких азотсодержащих групп приводит к повышению биоцидной активности полимеров. Кроме того, было показано, что активность полимерных катионов (например, политриалкилвинилбензиламмонийхлорида и поливинилпиридинийбромида) и воздействие их на золотистый стафилококк и дрожжи в 3-15 раз превышает активность их мономеров [5].

Среди широкого спектра полимерных биоцидов выделяется группа соединений, содержащих в своём составе гуанидиновую группировку (ПГМГ). Гуанидин - фрагмент аминокислот и витамина $\mathrm{B}_{6}$ - содержится в яичном альбумине, стрептомицине и многих белках, входит в состав гуано. Гуанидин имеет формулу $\left(\mathrm{H}_{2} \mathrm{~N}\right)_{2} \mathrm{C}=\mathrm{NH}$. Он легкодоступен, высокоэффективен, обладает широким спектром бактерицидного действия и при этом является малотоксичным, не проникает через кожу и не накапливается в организме. ПГМГ впервые был синтезирован в США в 1943 году [25]. В России гуанидиновые антисептики впервые были синтезированы в институте

Таблица 1. Бактерицидная активность различных соединений

\begin{tabular}{|c|c|c|c|c|c|}
\hline \multirow{2}{*}{$\begin{array}{l}\text { Наименование } \\
\text { микроорганизма }\end{array}$} & \multirow{2}{*}{$\begin{array}{l}\text { Номер } \\
\text { штамма }\end{array}$} & \multicolumn{4}{|c|}{$\begin{array}{c}\text { Минимальная бактерицидная концентрация } \\
\text { по препарату, \% }\end{array}$} \\
\hline & & ПгМГ & $\begin{array}{l}\mathrm{N} \text {-цетил! } \\
\text { пиридин }\end{array}$ & $\begin{array}{c}\text { Катамин } \\
\mathrm{AB}\end{array}$ & Амфолан \\
\hline Escherichia coli & ATCC 25922 & 0,007 & 0,025 & 0,012 & 0,012 \\
\hline Escherichia coli & $5-3$ & 0,007 & 0,025 & 0,012 & 0,012 \\
\hline Escherichia coli & 101 & 0,007 & 0,05 & 0,05 & 0,012 \\
\hline Escherichia coli & "Ser" & 0,007 & 0,025 & 0,02 & 0,025 \\
\hline Escherichia colit & K-12 & 0,0035 & 0,05 & 0,05 & 0,025 \\
\hline Pseudomonas aeruginosa & MHTK & 0,0035 & $0,5-1$ & 0,012 & 0,025 \\
\hline Pseudomonas aeruginosa & ATCC9027 & 0,007 & $0,5-1$ & 0,012 & 0,025 \\
\hline Proteus mirabilis & 185 & 0,015 & 0,05 & 0,025 & 0,1 \\
\hline Proteus mirabilis & «Poliakov» & 0,035 & 0,05 & 0,025 & 0,1 \\
\hline Proteus mirabilis & 286 & 0,025 & 0,015 & 0,05 & 0,2 \\
\hline Proteus mirabilis & 99 & 0,015 & 0,025 & 0,05 & 0,2 \\
\hline Proteus vulgaris & HX19 & 0,031 & 0,01 & 0,025 & 0,1 \\
\hline Klebsiellapneumoniae & 401 & 0,015 & 0,01 & 0,05 & 0,05 \\
\hline Klebsiellapneumoniae & 244 & 0,007 & 0,05 & 0,05 & 0,05 \\
\hline Serratia marcescens & MHTK & 0,0125 & $0,5-1,0$ & 0,15 & 0,1 \\
\hline Serratia marcescens & 104 & 0,012 & 1,0 & 0,15 & 0,1 \\
\hline Staphylococcus aureus & 1094 & 0,00042 & 0,006 & 0,0025 & 0,005 \\
\hline Staphylococcus aureus & 488 & 0,00084 & 0,006 & 0,00125 & 0,005 \\
\hline Staphylococcus aureus & "Wood" & 0,00084 & 0,006 & 0,005 & 0,005 \\
\hline Enterococcus faecalis & 155 & 0,0035 & 0,015 & 0,012 & 0,8 \\
\hline Salmonellatyphimurium & Wild & 0,007 & 0,012 & 0,025 & 0,012 \\
\hline Salmonellatyphimurium & Wild & 0,0035 & 0,012 & 0,12 & 0,05 \\
\hline Salmonellatyphimurium & 19 & \multicolumn{2}{|c|}{0,0012} & \multicolumn{2}{|c|}{ Не действует } \\
\hline Francisella tularensis & - & \multicolumn{2}{|c|}{0,8} & \multicolumn{2}{|c|}{ * } \\
\hline Candida albicans & ATCC $885-663$ & 0,007 & 0,025 & 0,025 & 0,0025 \\
\hline
\end{tabular}

нефтехимического синтеза РАН П.А. Гембицким с сотрудниками путём поликонденсации гексометилендиомина (ГМДА) с гидрохлоридом гуанидина (ГХГ) [26; 27]. Их бактерицидное действие определяется способностью производныхгуанидина связываться с клеточными стенками и мембранами бактерий, проникать в ядро клеток и ингибировать клеточные ферменты [5]. Способность связываться с мембранами в основном определяется наличием в макромолекуле положительно заряженных групп (четвертичных аммонийных групп) и наличием на поверхности клетки отрицательного заряда, обусловленного фосфатными группами липидов. Производные гуанидина проявляют наивысшую активность при наличии у заместителей 5-8 атомов углерода, и эти свойства сохраняются при включении гуанидина в полимерные композиции [5].

Нами проанализировано более трёхсот патентов, посвящённых производным гуанидина. Установлено, что их число с 2-5 в 1970-е годы превысило 20 к концу 1990-х годов. Большая их часть - около 300 - международные и европейские патенты, что свидетельствует о значении, которое придаётся в зарубежных странах разработкам, связанным с использованием производных гуанидина. Рост динамики патентования также указывает на повышение интенсивности исследований, их перспективности и наличие растущего спроса на препараты производных гуанидина на мировом рынке. Исследование тематики патентов показало, что около $70 \%$ касается создания новых химических соединений и препаратов на их основе, остальные посвящены совершенствованию технологии их получения. Свыше 50\% патентов связаны с разработкой новых лекарственных препаратов, 20\% - биоцидных, 30\% - с использованием производных гуанидина в химической, ракетной, пищевой и косметической промышленностях. В медицине производные гуанидина находят применение в качестве препаратов противовоспалительного, противоопухолевого, сердечно-сосудистого, антишокового, иммуностимулирующего, анальгетического и нейрозащитного действия.

Несмотря на большое количество разработок по данным фунгицидным соединениям следует отметить, что исследования в части разработки биостойких строительных материалов, изделий на их основе далеко не исчерпаны.

На первом этапе нами проведены сравнительные исследования бактерицидного действия ПГМГ и других добавок. Исследования (табл. 1) показали минимальную бактерицидную концентрацию по ПГМГ в сравнении с N-цетилпиридином, катамином $\mathrm{AB}$ и амфоланом.

Второй этап исследований заключался в разработке модифицированных ПГМГ. Исследования заключались в получении органических кислот, различающихся по структуре и индуктивным эффектам, и определении влияния структуры кислоты на биоцидную активность препарата. Содержание кислот в препарате принималось равным 3\%. Результаты исследований представлены в таблице 2.

Из результатов следует, что биоцидный эффект зависит от строения кислоты. Наличие в её молекуле донорных или акцепторных групп определяет её ионную силу (pК). Чем сильнее кислота, тем выше биоцидный эффект препарата (при прочих равных условиях). 
В результате исследования разработана технология получения олигомеров из различных ингредиентов, что позволило увеличить спектр применения, повысить эффективность и улучшить сорбционные характеристики композиций. Конечный биоцидный препарат содержит олигомер солей ПГМГ с общей формулой

$$
\begin{aligned}
\mathrm{H}-[\mathrm{NH}-\mathrm{C}-\mathrm{NH}- & \left.\left(\mathrm{CH}_{2}\right)_{6}\right]_{\mathrm{b}}-\left[\mathrm{NH}-\mathrm{C}-\mathrm{NH}-\left(\mathrm{CH}_{2}\right)_{6}\right]_{\mathrm{c}}- \\
& -\mathrm{H}_{2} \mathrm{~N}^{+} \mathrm{X}-\mathrm{H}_{2} \mathrm{~N}^{+} \mathrm{A},
\end{aligned}
$$

где X - анионы минеральных кислот (соляной, плавиковой,фосфорной); А - анионы органических кислот (муравьиной, лимонной, уксусной, олеиновой, стеариновой, глюконовой) в соотношении $\mathrm{b} / \mathrm{b}+\mathrm{c}=0,6 \ldots 0,99$ и $\mathrm{c} / \mathrm{b}+\mathrm{c}=0,01 \ldots 0,04$ со средней молекулярной массой $1500 \pm 600$ и n $=5 . . .12$.

В зависимости от области применения олигомера разработаны методики его получения: путём смешивания соответствующего количества каждого из компонентов в водном растворе при комнатной температуре с последующим перемешиванием в течение 20-30 мин до достижения равновесия; путём обработки олигомера ПГМГ-Х соответствующими кислотами и выдерживанием смеси до достижения полной однородности водного или водно-спиртового раствора.

На третьем этапе исследований установлена комплексообразующая способность макромолекул ПГМГ образовывать комплексы схлоридом железа и проведено количественное измерение этой способности. Образование комплекса приводит к структурированию системы и повышению вязкости препарата.

На четвёртом этапе выявлена зависимость количества примесей в ПГМГ от температурной обработки реакционной смеси на стадии синтеза. Токсичность препарата снижается путём удаления аммиака при температурной обработке ( $\mathrm{t}>150-220$ $\left.{ }^{\circ} \mathrm{C}\right)$. Хроматографические исследования (рис. 1) показывают, что содержание примесей уменьшается более чем на порядок.

При сравнении хроматограмм можно сделать вывод об отсутствии примесей во втором и третьем образцах (пик со временем выхода около 24 мин принадлежит меламину), первый образец (полисепт) отличает наличие большого числа низкомолекулярных примесей.

Таблица 2. Влияние структуры кислоты на

\begin{tabular}{|c|c|c|c|c|c|c|c|c|c|}
\hline \multirow[b]{2}{*}{$\begin{array}{l}\text { Кислота } \\
\text { вводимая }\end{array}$} & & \multicolumn{8}{|c|}{ Диаметр зоны задержки роста микроорганизмов, мм } \\
\hline & & $\begin{array}{l}\overline{0} \\
\text { نे }\end{array}$ & 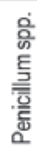 & 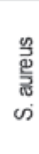 & 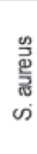 & 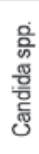 & 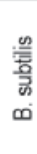 & 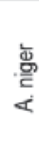 & 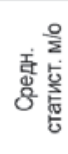 \\
\hline 1 & 2 & 3 & 4 & 5 & 6 & 7 & 8 & 9 & 10 \\
\hline \multirow{4}{*}{$\begin{array}{l}\text { Лимонная } \\
\mathrm{pK}=2,94\end{array}$} & 0,05 & 7 & 7 & 8 & 8 & 5 & 9 & 5 & 7 \\
\hline & 0,1 & 11 & 10 & 9 & 11 & 5 & 9 & 5 & $8-9$ \\
\hline & 0,5 & 12 & 15 & 12 & 14 & 10 & 13 & 10 & 12 \\
\hline & 1,0 & 12 & 20 & 12 & 14 & 10 & 14 & 14 & 14 \\
\hline \multirow{4}{*}{$\begin{array}{l}\text { Уксусная } \\
\text { pK }=4,76\end{array}$} & 0,05 & 5 & 7 & 6 & 5 & 6 & 6 & 5 & 6 \\
\hline & 0,1 & 5 & 7 & 6 & 5 & 6 & 6 & 5 & 6 \\
\hline & 0,5 & 8 & 18 & 9 & 5 & 7 & 10 & 5 & 9 \\
\hline & 1,0 & 13 & 24 & 11 & 8 & 12 & 12 & 5 & 12 \\
\hline \multirow{4}{*}{$\begin{array}{c}\text { Муравьиная } \\
\mathrm{pK}=3,77\end{array}$} & 0,05 & 5 & 12 & 5 & 5 & 5 & 5 & 5 & 6 \\
\hline & 0,1 & 5 & 15 & 6 & 6 & 5 & 5 & 5 & 7 \\
\hline & 0,5 & 9 & 26 & 7 & 10 & 8 & 11 & 5 & 11 \\
\hline & 1,0 & 10 & 32 & 9 & 10 & 8 & 15 & 6 & 13 \\
\hline
\end{tabular}
биоцидную активность препарата
Технологическая схема приготовления препаратов под торговой маркой «Тефлекс» приведена на рисунке 2.

В твёрдом виде олигомеры ПГМГ - это стеклоподобные вещества без цвета и запаха, хорошо растворимые в воде, спирте и других органических растворителях, с характеристической вязкостью 0,04-0,2 дл/г, нетоксичные. Олигомеры в растворах с концентрацией больше 0,01\% характеризуются повышенной антибактериальной и фунгицидной активностью. Наличие разных функциональных групп обусловливает способность препарата к повышенной адгезии на различных поверхностях.

На пятом этапе осуществлён анализ разработанных методик получения универсальных биоцидных композиций с широким спектром свойств. В результате проведённых

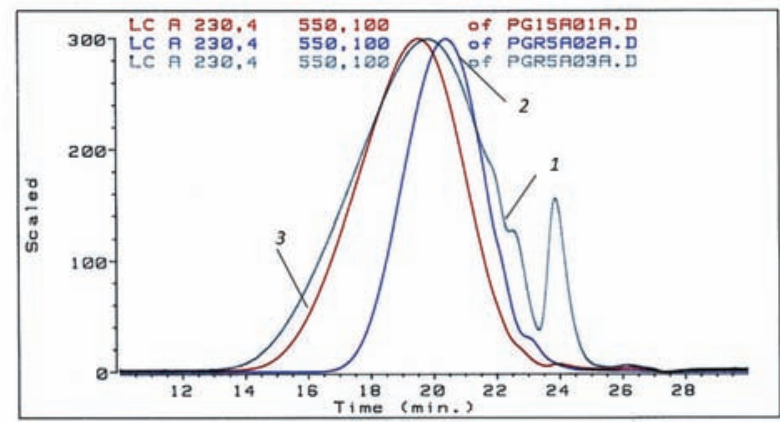

1 - исходный полисепт, 2 - температурное воздействие в течение 50 мин, 3 - то же, в течение 120 мин

Puс. 1. Хроматограммы образцов препарата в зависимости от высоко-температурной обработки

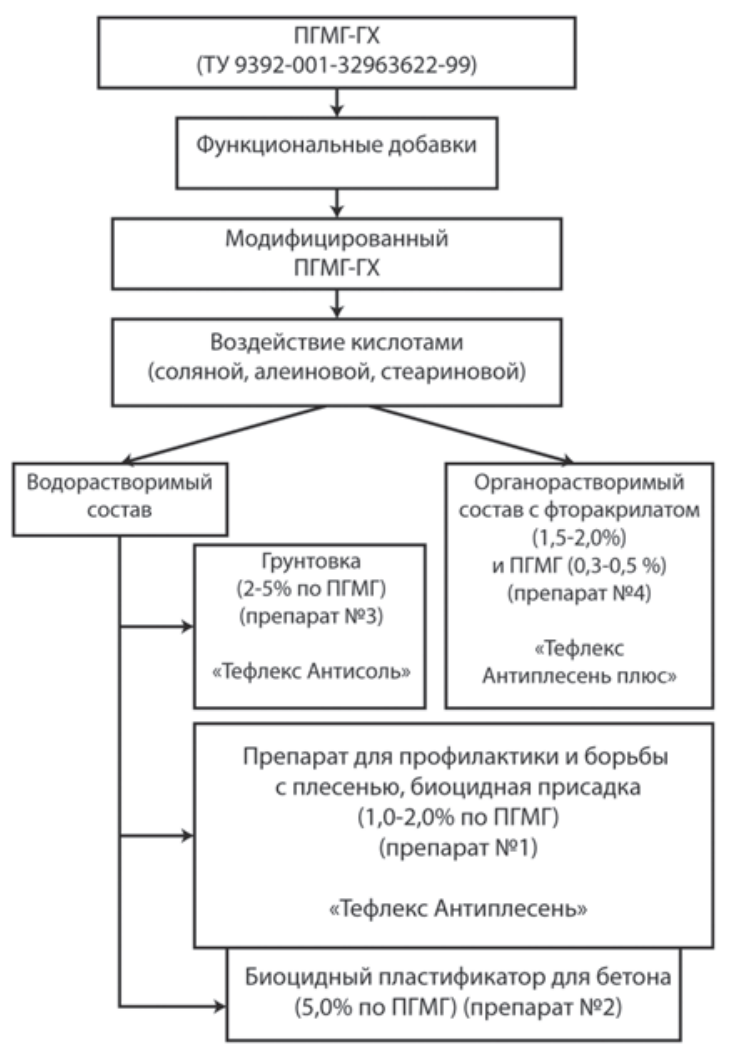

Рис. 2. Технологическая схема приготовления препаратов «Терлекс» 
исследований разработаны и апробированы методики получения препаративных средств, уменьшающих бактериальную обсеменённость помещений, приборов и инструментов.

С целью создания препарата, сочетающего эффективную бактерицидность с эксплуатационными характеристиками, присущими фторакрилату (гидрофобность, сохранение влагогазо-

Таблица 3. Результаты испытаний биоцидной активности препаратов

\begin{tabular}{|c|c|c|c|c|c|c|c|c|}
\hline \multirow[b]{2}{*}{ Препарат } & \multirow[b]{2}{*}{$\begin{array}{c}\text { Концентрация } \\
\%\end{array}$} & \multicolumn{7}{|c|}{$\begin{array}{c}\text { Диаметр зоны задержки роста } \\
\text { микроорганизмов под влиянием препаратов, мм }\end{array}$} \\
\hline & & 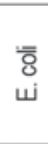 & 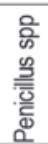 & 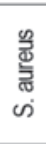 & 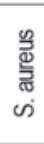 & 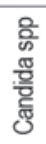 & 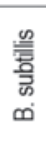 & 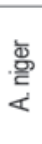 \\
\hline \multirow{3}{*}{ ПГМГ-Х } & 0,1 & 5 & 7 & 6 & 5 & 6 & 6 & 5 \\
\hline & 0,5 & 8 & 18 & 9 & 5 & 7 & 10 & 5 \\
\hline & 1,0 & 13 & 24 & 11 & 8 & 12 & 12 & 5 \\
\hline \multirow{3}{*}{$\begin{array}{l}\text { ПГМГ-X+ } \\
\text { фторакрилат }\end{array}$} & 0,1 & 6 & 13 & 5 & 6 & 5 & 5 & 5 \\
\hline & 0,5 & 8 & 20 & 8 & 12 & 8 & 9 & 6 \\
\hline & 1,0 & 8 & 20 & 12 & 12 & 12 & 13 & 7 \\
\hline
\end{tabular}

Таблица 4. Бактериостатическая эффективность композицией с фторакрилатом на поверхности обсемененные микроорганизмами

\begin{tabular}{|l|r|r|r|r|r|r|}
\hline \multicolumn{1}{|c|}{ Поверхность } & \multicolumn{3}{c|}{ Опыт KOE/cм² $(\dot{X})$} & \multicolumn{3}{c|}{ Контроль KOE $/ \mathrm{cm}^{2}(\dot{X})$} \\
\hline Стекло & 2,9 & 3,0 & 2,8 & 12,9 & 20,0 & 25.0 \\
\hline Металл & 4,5 & 4,6 & 4,8 & 7,6 & 52,6 & 74,0 \\
\hline Касель & 11,0 & 11,2 & 11,1 & 19,6 & 37,2 & 80,0 \\
\hline Масляная краска & 5,1 & 5,2 & 4,9 & 11,3 & 48,4 & 120,0 \\
\hline Ткань & 10,1 & 10,0 & 10,2 & 25,5 & 40,0 & 100,0 \\
\hline
\end{tabular}

Таблица 5. Результаты исследования действия биоцидных препаратов

\begin{tabular}{|c|c|c|c|c|c|}
\hline \multirow{2}{*}{$\begin{array}{l}\text { Вид } \\
\text { микробов }\end{array}$} & \multirow{2}{*}{$\begin{array}{l}\text { Разведение } \\
\text { ПГМГ, \% }\end{array}$} & \multicolumn{4}{|c|}{$\begin{array}{c}\text { Зона отсутствия роста микроорганизмов } \\
\text { вокруг препарата, мм }\end{array}$} \\
\hline & & №1 & № 2 & № 3 & № 4 \\
\hline E. coli & $\begin{array}{l}1 \\
0,1 \\
0,01 \\
0,001\end{array}$ & $\begin{array}{l}4 \\
1 \\
0,5 \\
0,2\end{array}$ & $\begin{array}{l}3 \\
1 \\
0,5 \\
0,1\end{array}$ & 3 & 2,5 \\
\hline S. aureus & $\begin{array}{l}1 \\
0,1 \\
0,01 \\
0,001\end{array}$ & $\begin{array}{l}6 \\
2 \\
1 \\
0\end{array}$ & $\begin{array}{l}7 \\
4 \\
2 \\
0\end{array}$ & 6 & 5,5 \\
\hline $\begin{array}{l}\text { Candida } \\
\text { spp. }\end{array}$ & $\begin{array}{l}1 \\
0,1 \\
0,01 \\
0,001\end{array}$ & $\begin{array}{l}4 \\
1 \\
0 \\
0\end{array}$ & $\begin{array}{l}4 \\
2 \\
0 \\
0\end{array}$ & 5,5 & 0 \\
\hline $\begin{array}{l}\text { Aspergilu } \\
\text { s spp. }\end{array}$ & $\begin{array}{l}1 \\
0,1 \\
0,01 \\
0,001\end{array}$ & $\begin{array}{c}4 \text { (ингибиция) } \\
0 \\
0 \\
0\end{array}$ & $\begin{array}{c}4 \text { (ингибиция) } \\
0 \\
0 \\
0\end{array}$ & 3 & 4 \\
\hline
\end{tabular}

обмена, пролонгированное действие), разработана технология получения новой композиции, состоящей из олигомера ПГМГ и фторакрилата (препарат № 4). Биоцидная активность олигомеров ПГМГ, содержащих гидрофобизатор, в качестве которого использовали фторакрилат, различна (табл. 3).

Полученные композиции обладают свойствами олигомера и фторакрилата. Срок их биоцидного действия увеличен до нескольких лет, биоцидная активность олигомеров в составе композиции не снизилась, а в некоторых случаях оказалась выше при сохранении основных свойств препарата.

Состав композиции можно установить с учётом обрабатываемого материала, особенностей эксплуатации объектов защиты, видов микроорганизмов, вызывающих биодеградацию, и экономической оценки [28].

Биоцидное действие гидрофобной композиции с фторакрилатом изучали с использованием культуры E. coli (штамм M 17), выращенной на глюкозосодержащей питательной среде (концентрация 1,5 млрд кл./мл). При обработке чашек с культурой путём разбрызгивания препарата в течение 1 сек с расстояния 15 см диаметр колоний снизился в полтора-два раза по сравнению с контролем, число колоний уменьшилось в десять раз. Установлена бактериостатическая эффективность воздействия композицией с фторакрилатом через определённые промежутки времени (с интервалом в 7 суток) на различные поверхности, обсеменённые микроорганизмами (табл. 4).

В результате исследования разработана технология получения композиций с различными концентрациями ПГМГ в зависимости от объектов защиты и материалов, из которых они изготовлены. Воздух в помещениях обрабатывается путём распыления препарата № 1, для обработки стен и оборудования используются препараты №№ 1-4 в виде аэрозоля, водного или спиртового раствора. При обработке тканей и резинотехнических изделий препарат № 4 наносят на материал путём распыления или замачивания. Исследования показали снижение бактериального фона в два-три раза.

«Тефлексы» (препараты №№ 1-4) имеют высокие эксплуатационные показатели (защищают от воздействия влажности, предотвращают заболеваемость, дезинфицируют воздух и поверхности, не оказывают токсичного воздействия), и их можно использовать в присутствии человека и животных. «Тефлексы» эффективны при использовании в строительстве, для борьбы с биоповреждениями, например, обрастанием плесенью, для обработки деревянных изделий, бетонных и других сооружений.

В таблице 5 приведены исследования действия биоцидных препаратов №№ 1-4 различных концентраций по отношению к различным микроорганизмам.

Из результатов исследований следует, что растворы всех препаратов высокоактивны против всех тестированных штаммов, в том числе бактерий, дрожжеподобных и плесневых грибов. Максимальную активность проявил препарат № 2, давший наибольшие зоны отсутствия роста вокруг дисков.

В настоящее время в РФ в качестве дезинфицирующих средств выпускают препараты «Полисепт» (ПГМГ-Х, твёрдая форма, 95 \%); 
«Биопаг-Д» и «БИОР-1» (20\% водный раствор ПГМГ-Х); «Тефлекс Антиплесень», «Тефлекс Антисоль смывка», «Тефлекс Реставратор», «Тефлекс Защита для металла» (1-5\% водный раствор ПГМГ-Х); биоцидный пластфикатор «Тефлекс-5» (1-5\% водный раствор ПГМГ-Х); средство «Тефлекс дезинфицирующий» (9,5-10,5\% водный раствор ПГМГ-Х); «Фосфопаг-Д» (20\% водный раствор ПГМГ-Ф); «Тефлекс индустриальный» (40\% водный раствор ПГМГ-Х) [28].

\section{Лuтература}

1. Андреюк, Е.И. Микробиологическая коррозия строительных сталей и бетонов / Е.И. Андреюк, И.А. Козлова, А.М. Рожанская // Биоповреждения в строительстве. - М., 1984. - С. 209-218.

2. Биологическое сопротивление материалов / В.И. Соломатов, В.Т. Ерофеев, В.Ф. Смирнов [и др.]. - Саранск : Изд-во Мордов. ун-та, 2001. - 196 с.

3. Биоповреждения в строительстве / Ф.М. Иванов, С.Н. Горшин, Дж. Уайт [и др.] ; под ред. Ф.М. Иванова, С.Н. Горшина. - М. : Стройиздат, 1984. - 320 с.

4. Бочаров, Б.В. Биостойкость материалов (стойкость к воздействию плесневых грибов, насекомых и грызунов) / Б.В. Бочаров, А.А. Герасименко, И.А. Коровина. - М. : Стройиздат, 1986. - 206 с.

5. Защита зданий и сооружений от биоповреждений биоцидными препаратами на основе гуанидина / под ред. П.Г. Комохова, В.Т. Ерофеева, Г.Е. Афиногенова. - СПб : Наука, 2010. - 192 с.

6. Ильичёв, В.Д. На стыке экологии и техники / В.Д. Ильичев // Биоповреждения в строительстве. - М., 1984. - С. 4-9.

7. Коваль, Э.З. Микодеструкторы промышленных материалов / Э.3. Коваль, Л.П. Сидоренко. - Киев : Наук. думка, 1989. - 192 с.

8. Лугаускас, А.Ю. Поражение полимерных материалов микромицетами / А.Ю. Лугаускас, Л.И. Левинскайте, Д.И. Лукшайте // Пластические массы. - 1991. - № 2. - С. 24-28.

9. Микодеструкторы строительных конструкций внутренних помещений предприятий пищевой промышленности / Э.З. Коваль, В.А. Серебреник, Е.Л. Рогинская, Ф. М. Иванов // Микробиологический журнал - 1991. - Т. 53. - № 4. - С. 96-103.

10. Sand, W. Microbial corrosion and its inhibition / W. Sand // Biotechnology. Vol. 10, 2nd ed. / Rehm H.J. (ed.). - Weinheim : Wiley-VCH Verlag, 2001. - P. 267-316.

11. Vincke, $E$. Analysis of the microbial communities on corroded concrete sewer pipes - a case study / E. Vincke, N. Boon, W. Verstraete // Applied Microbiology and Biotechnology. - 2001. - № 57. - P. 776-785.

12. Cwalina, $B$. Korozja kamienia i betonu wzbudzona przez drobnoustroje / B. Cwalina // Ochrona przed Korozją. - 2004. - №, 1. - P. 17-23. (in Polish).

13. Quantifying microbially induced deterioration of concrete: Initial studies / D.J. Roberts, D. Nica, G. Zuo, J.L. Davis // International Biodeterioration and Biodegradation. -2002. - № 49. - P. 227-234.

14. Eriksen, $K$. Thaumasite attack on concrete at Marbjerg Waterworks / K. Eriksen // Cement and Concrete Composites. - 2003. - № 25. - P. 1147-1150.
15. Biological resistance of cement composites filled with dolomite powders / Erofeev V., Kalashnikov V., Emelyanov D. [et al.] // Solid State Phenomena. - 2016. - № 871. - P. 33-39. DOI: 10.4028/www.scientific.net/MSF.871.33.

16. Videla, H.A. Microbiologically influenced corrosion: looking to the future / H.A. Videla, L.K. Herrera // International Microbiology. - 2005. - № 8 (3). - P. 169-180.

17. Development of Biocidal Cements for Buildings and Structures with Biologically Active Environments / Travush, V.I., Karpenko, N.I., Erofeev, V.T. [et al.] // Power Technology and Engineering. 2017. - № 51 (4). - P. 377-384. DOI: 10.1007/s10749-017-0842-8.

18. Оценка коррозии стеклощелочных композитов, прогнозирование их физико-химического сопротивления и способы его повышения / Ерофеев В.Т., Федорцов А.П., Богатов А.Д. [и др.] // Известия высших учебных заведений. Серия «Технология текстильной промышленности». - 2018. - № 2 (374). - С. 238-246.

19. Erofeev, V. Frame Construction Composites for Buildings and Structures in Aggressive Environments / V. Erofeev // Procedia Engineering. - 2016. - № 165. - Pp. 1444-1447. DOI: 10.1016/j.proeng.2016.11.877

20. Противодействие биоповреждениям на этапах строительства, эксплуатации и ремонта в жилых и производственных помещениях : учеб. пособие / В.Т. Ерофеев, Д.А. Светлов, С.В. Казначеев [и др.]; под общ. ред. акад. РААСН В.Т. Ерофеева. - Саранск : Изд-во Мордов. ун-та, 2017. - 172 с.

21. Старцев, С.А. Методы ликвидации последствий биоповреждения строительных конструкций. Биоповреждения и биокоррозия в строительстве: Материалы Междунар. науч.техн. конф. - Саранск: Изд-во Мордов. ун-та, 2004. - с. 15-20.

22. Смирнов, В.Ф. О влиянии фунгицидов на активность кислых, нейтральных и щелочных липаз Rhizopus oryzae / В.Ф. Смирнов, А.Н. Леонтьева, М.В. Воробьева // Регуляция ферментативной активности у растений. - Горький, 1990. - С. 35-39.

23. Анисимов, A.А. 0 биохимических механизмах действия фунгицидов / А.А. Анисимов, И.Ф. Александрова // Биоповреждения в промышленности. - Горький, 1983. - С. 7-17.

24. Фельдман, М.С. Эффективные фунгициды на основе смол термической переработки древесины / М.С. Фельдман, Ю.М. Гольдшмидт, М.3. Дубиновский // Биоповреждения в промышленности : тез. докл. конф. : в 2 ч. Ч. 1. - Пенза, 1993. - С. 86-87.

25. Bolton, E.K. Полимерные гуанидины и процесс их получения / Bolton E.K., Coffmon D.D. - USP, Z60 2. - 1943. - № 2. - P. 325, 586.

26. Данилина Н.И. Гембицкий П.А., Кузнецов 0.Ю., Боронина Т.В., Способ получения полимера гексометилендиамина. А.С. СССР №1808832 Б.И. 1993, №14

27. Сафонов Г.А., Гембицкий Л.А., Кузнецов 0.Ю., Клюев В.Г., Калинина Т.А., Родионов А.В. Способ получения дезинфицирующего средства // А.С. СССР № 1616898, Б.И. 1990, №48

28. Патент № 2142293 Российской Федерации, МПК A61L2/16, C1. Биоцидный препарат / Д. А. Светлов, Д. А. Топчиев, П. А. Гембицкий и др.; Заявитель и патентообладатель Д. А. Светлов, П. А. Гембицкий и др. 98116901/13; заявл. 02.11.1998; опубл. 10.12.1999. № 34. С 173. 


\section{References}

1. Andreyuk E.I., Kozlova I.A., Rozhanskaya A.M. Mikrobiologicheskaya korroziya stroitel'nykh stalei i betonov [Microbiological corrosion of building steels and concretes]. Biopovrezhdeniya $v$ stroitel'stve [Bio-damage in construction]. Moscow, 1984, pp. 209-218.

2. V.I. Solomatov, V.T. Erofeev, V.F. Smirnov [et al.]. Biologicheskoe soprotivlenie materialov. Saransk, Mordovia State University Publ., 2001, 196 p.

3. F.M. Ivanov, S.N. Gorshin, Dzh. Uait [et al.]. Biopovrezhdeniya $v$ stroitel'stve [Bio-damage in construction], F.M. Ivanova, S.N. Gorshina (eds.). Moscow, Stroiizdat Publ., 1984, 320 p.

4. Bocharov B.V., Gerasimenko A.A., Korovina I.A. Biostoikost' materialov (stoikost' k vozdeistviyu plesnevykh gribov, nasekomykh i gryzunov) [Biostightness of materials (resistance to mold fungi, insects and rodents)]. Moscow, Stroiizdat Publ., 1986, 206 p.

5. Zashchita zdanii i sooruzhenii ot biopovrezhdenii biotsidnymi preparatami na osnove guanidine [Protection of buildings and structures from biological damage with biocidal preparations based on guanidine], P.G. Komokhova, V.T. Erofeeva, G.E. Afinogenova (eds.). Saint Petersburg, Nauka Publ., 2010, 192 p.

6. Il'ichev V.D. Na styke ekologii i tekhniki [At the intersection of ecology and technology]. Biopovrezhdeniya $v$ stroitel'stve [Biological damage in construction]. Moscow, 1984, pp. 4-9.

7. Koval' E.Z., Sidorenko L.P. Mikodestruktory promyshlennykh materialov [Mikodestruction of industrial materials]. Kiev, Naukova dumka Publ., 1989, 192 p.

8. Lugauskas A.Yu. Levinskaite L.I., Lukshaite D.I. Porazhenie polimernykh materialov mikromitsetami [Damaging of polymeric materials by micromycetes]. Plasticheskie Massy [Plastics.], 1991, no. 2, pp. 24-28.

9. Koval'E.Z., Serebrenik V.A., Roginskaya E.L., Ivanov F.M. Mikodestruktory stroitel'nykh konstruktsii vnutrennikh pomeshchenii predpriyatii pishchevoi promyshlennosti [Mikodestruction of building structures inside the premises of food industry enterprises]. Mikrobiologicheskii zhurnal [Microbiological journal], 1991, Vol. 53, no. 4, pp. 96-103.

10. Sand W. Microbial corrosion and its inhibition. In: Rehm H.J. (Ed.), Biotechnology, Vol. 10, 2nd ed. Wiley-VCH Verlag, Weinheim, 2001, pp. 267-316.

11. Vincke E., Boon N., Verstraete W. Analysis of the microbial communities on corroded concrete sewer pipes - a case study. Applied Microbiology and Biotechnology, 2001, no. 57, p. 776-785.

12. Cwalina B.; Korozja kamienia i betonu wzbudzona przez drobnoustroje [The stone and concrete corrosion influenced by microorganisms]. Ochrona przed Korozja, 2004, no.1, pp. 17-23.

13. Roberts D.J., Nica D., Zuo G., Davis J.L. Quantifying microbially induced deterioration of concrete: Initial studies. International Biodeterioration and Biodegradation, 2002, no. 49, pp. 227-234.

14. Eriksen K.; Thaumasite attack on concrete at Marbjerg Waterworks. Cement and Concrete Composites, 2003, no. 25, pp. 1147-1150.
15. Erofeev V., Kalashnikov V., Emelyanov D., Balathanova E., Erofeeva I., Smirnov V., Tretiakov I., Matvievskiy A. Biological resistance of cement composites filled with dolomite powders. Solid State Phenomena, 2016, no. 871, pp. 33-39. D0I: 10.4028/ www.scientific.net/MSF.871.33.

16. Videla H.A., Herrera L.K.; Microbiologically influenced corrosion: looking to the future. International Microbiology, 2005, no. 8 (3), pp. 169-180.

17. Travush V.I., Karpenko N.I., Erofeev V.T., Rodin A.I., Smirnov V.F., Rodina N.G. Development of Biocidal Cements for Buildings and Structures with Biologically Active Environments. Power Technology and Engineering, 2017, no. 51 (4), pp. 377-384. D0I: 10.1007/s10749-017-0842-8.

18. Erofeev V.T., Fedortsov, A.P., Bogatov, A.D., Fedortsov, V.A., Gusev, B.V. Otsenka korrozii stekloshchelochnykh kompozitov, prognozirovanie ikh fiziko-khimicheskogo soprotivleniya i sposoby ego povysheniya [Evaluation of corrosion of alkaliglass composites, predicting their physico-chemical resistance and ways to improve it]. Izvestiya Vysshikh Uchebnykh Zavedenii, Seriya Teknologiya Tekstil'noi Promyshlennosti [News of higher educational institutions. Series "Technology of the textile industry"], 2018, no. 2 (374), pp. 238-246.

19. Erofeev V. Frame Construction Composites for Buildings and Structures in Aggressive Environments. Procedia Engineering, 2016, no. 165, pp. 1444-1447. D0I: 10.1016/j. proeng.2016.11.877.

20. Erofeev V.T., Svetlov D.A., Kaznacheev S.V. [et al.] Protivodeistvie biopovrezhdeniyam na etapakh stroitel'stva, ekspluatatsii i remonta $\vee$ zhilykh i proizvodstvennykh pomeshcheniyakh [Counteraction to biodeterioration at the stages of construction, operation and repair in residential and industrial premises: textbook. allowance], ucheb. posobie, V.T. Erofeev (ed.). Saransk, Mordovia State University Publ., 2017, 172 p.

21. StartsevS.A. Metodylikvidatsii posledstvii biopovrezhdeniya stroitel'nykh konstruktsii [Methods of eliminating the effects of biodeterioration of building structures]. Biopovrezhdeniya $i$ biokorroziya v stroitel'stve: Materialy Mezhdunar. nauch.-tekhn. konf. [Biodeterioration and biocorrosion in construction: Materials of Intern. scientific and technical conf.]. Saransk, Mordovia State University Publ., 2004, pp. 15-20.

22. Smirnov V.F., Leont'eva A.N., Vorob'eva M.V. 0 vliyanii fungitsidov na aktivnost' kislykh, neitral'nykh i shchelochnykh lipaz Rhizopus oryzae [0n the effect of fungicides on the activity of acid, neutral and alkalinelipases of Rhizopus oryzae]. Regulyatsiya fermentativnoi aktivnosti u rastenii [Regulation of enzymatic activity in plants]. Gor'ky, 1990, pp. 35-39.

23. Anisimov A.A., Aleksandrova I.F. 0 biokhimicheskikh mekhanizmakh deistviya fungitsidov [About biochemical mechanisms of action offungicides]. Biopovrezhdeniya v promyshlennosti [Biological damages in industry]. Gor'ky, 1983, pp. 7-17.

24. Fel'dman M.S., Gol'dshmidt Yu.M., Dubinovskii M.Z. Effektivnye fungitsidy na osnove smol termicheskoi pererabotki drevesiny [Effective fungicides based on resins of thermal processing 
of wood]. Biopovrezhdeniya $v$ promyshlennosti [Biological damages in industry], tez. dokl. konf. In 2 parts. P. 1. Penza, 1993, pp. 86-87.

25. Bolton E.K., Coffmon D.D. Polimernye guanidiny $i$ protsess ikh polucheniya [Polymer guanidines and the process of their preparation]. USP, Z60 2, 1943, no. 2, pp. 325, 586.

26. Danilina N.I. Gembitskii P.A., Kuznetsov 0.Yu., Boronina T.V., Sposob polucheniya polimera geksometilendiamina [Method for the production of hexomethylenediamine polymer]. A.S. SSSR № 1808832 B.I. 1993, №14.
27. Safonov G.A., Gembitskii L.A., Kuznetsov 0.Yu., Klyuev V.G., Kalinina T.A., Rodionov A.V. Sposob polucheniya dezinfitsiruyushchego sredstva [A method of obtaining a disinfectant].A.S. SSSR № 1616898, B.I. 1990, №48.

28. Patent № 2142293 Rossiiskoi Federatsii, MPK A61L2/16, S1. Biotsidnyi preparat / D. A. Svetlov, D. A. Topchiev, P. A. Gembitskii i dr.; Zayavitel' i patentoobladatel' D. A. Svetlov, P. A. Gembitskii i dr. 98116901/13; zayavl. 02.11.1998; opubl. 10.12.1999. № 34. S 173.

Ерофеев Владимир Трофимович (Саранск). Доктор технических наук, профессор, академик РААСН. Заведующий кафедрой строительных материалов и технологий, декан архитектурно-строительного факультета ФГБОУ В0 «МГУ им. Н.П. Огарёва» (430000, г. Саранск, Советская, 24). Эл почта: AL_Rodin@mail.ru.

Светлов Дмитрий Анатольевич (С.-Петербург). Кандидат технических наук, доцент. Генеральный директор 000 «Софт Протектор» (195030, С.-Петербург, ул. Химиков, дом 28, лит. Ц. Софт-Протектор). Эл. почта: teflex@list.ru.

Смирнов Василий Филлипович (Н. Новгород). Доктор биологических наук, профессор. Заведующий химико-биологическим отделом НИИ химии ФГБОУ В0 «Нижегородский государственный университет» (603022, Н.Новгород, просп. Гагарина, 23, кор. 5. ННГУ им. Н.И.Лобачевского). Эл. почта: AL_Rodin@mail.ru.

Краева Людмила Александровна (С.-Петербург). Доктор медицинских наук, доцент. Заведующая лабораторией медицинской бактериологии ФБУН «НИИ эпидемиологии и микробиологии имени Пастера» (197101, Санкт-Петербург, ул. Мира, д. 14. НИИЭМ имени Пастера), профессор кафедры микробиологии Военно-медицинской академии им. С.М.Кирова. Эл. почта: lykraeva@yandex.ru.

Лубченков Михаил Анатольевич (С.-Петербург). Ph.D. клеточная биология, МBA финансы. Научный консультант 000 «Софт Протектор». Эл. почта: mlsuo@yahoo.com.

Светлов Даниил Дмитриевич (С.-Петербург) Студент Высшей школы биотехнологий и пищевых производств (194021, СанктПетербург, ул. Новороссийская, 48-50. ВШБТиПП). Эл. почта: svetlov-dan@mail.ru.

Erofeev Vladimir T. (Saransk). Doctor of Technical Sciences, Professor, Academician of RAACS. Head of the Department of Building Materials and Technologies, Dean of the Faculty of Architecture and Construction Engineering at the Ogarev Mordovia State University (24 Sovetskaya Str., Saransk, 430000. MRSU). E-mail: AL_Rodin@mail.ru.

Svetlov Dmitry A. (Saint Petersburg). Candidate of Technical Sciences, Associate Professor. General Director of 000 "Soft-Protector" (28 Khimikov Str., St. Petersburg, 195030. Soft Protector). E-mail: teflex@list.ru

Smirnov Vasily F. (N. Novgorod). Doctor of Biological Sciences, Professor. Head of the Chemical and Biological Department of Research Institute of Chemistry of Nizhny Novgorod State University (603022, N. Novgorod, 23 Gagarina Ave., Building 5. UNN named after N.I. Lobachevsky).E-mail: AL_Rodin@mail.ru.

Kraeva Lyudmila A. (Saint Petersburg). Doctor of Medical Sciences, Associate Professor. Head of the Laboratory of Medical Bacteriology of the Pasteur Research Institute of Epidemiology and Microbiology (14, Mira str., St Petersburg, 197101. Pasteur Institute), Professor of the Department of Microbiology at the S.M. Kirov Military Medical Academy. E-mail:lykraeva@yandex.ru.

Lubchenkov Mikhail A. (St. Petersburg). Candidate of Cell Biology. MBA. Scientific Advisor 000 "Soft-Protector". E-mail: mlsuo@ yahoo.com.

Svetlov Daniil D. (Saint Petersburg). Student of bachelor's degree at the Graduate school of biotechnology and food science (48-50 Novorossijskaya Str., St. Petersburg, 194021. GSB\&FS). E-mail:svetlov-dan@mail.ru 